\title{
Current Minimum Inhibitory Concentration (MIC) of Halquinol against Local Pathogenic Bacterial Isolates of Poultry
}

\author{
B. H. Pavithra ${ }^{1^{*}}$, N. Prakash $^{2}$, G. Leena ${ }^{3}$ and C. R. Santhosh ${ }^{1}$ \\ ${ }^{1}$ Department of Pharmacology \& Toxicology, Veterinary College, \\ Bengaluru-560024, India \\ ${ }^{2}$ Veterinary College, Shivamogga- 577 204, India \\ ${ }^{3}$ Department of Public Health and Epidemiology, Veterinary College, \\ Bengaluru-560024, India \\ *Corresponding author
}

\section{A B S T R A C T}

\begin{tabular}{|l|}
\hline K e y w o r d s \\
$\begin{array}{l}\text { Halquinol, } \\
\text { pathogenic } \\
\text { bacterial isolates, } \\
\text { poultry, MIC }\end{array}$ \\
\hline Article Info \\
\hline $\begin{array}{l}\text { Accepted: } \\
\text { 10 July } 2020 \\
\text { Available Online: } \\
\text { 10 August } 2020\end{array}$ \\
\hline
\end{tabular}

Halquinol, a quinoline derivative having antibacterial, antifungal and antiprotozoal activity was introduced across the world to overcome common challenges of modern poultry and swine farming, like pathogenic microbial infections and growth promotion aspects. In Asian countries including India, halquinol is being extensively used as growth promoter in poultry and to control intestinal infections, which may contribute towards the development of resistance against it. And also, as minimum inhibitory concentration (MIC) of antimicrobials against microbial pathogens changes with place and time, the present study was conducted to determine the current MIC of halquinol against local pathogenic bacterial isolates from poultry. In the present study two individual isolates from poultry viz., Salmonella gallinarum and Escherichia coli were used as test bacteria. The MIC of halquinol was determined by employing broth dilution technique following standard protocol. The MIC was determined as the lowest concentration of halquinol that completely inhibited the growth of bacteria. The MIC of halquinol against both the local pathogenic isolates from poultry viz: Escherichia coli and Salmonella gallinarum was 4 $\mu \mathrm{g} / \mathrm{mL}$. Thus, despite the widespread usage, the development of resistance against halquinol did not cross the global optimal MIC reported in the year 2015

\section{Introduction}

Halquinol is a mixture obtained by chlorinating quinolin-8-ol. It contains not less than 57 per cent and not more than 74 per cent of 5, 7-dichloroquinolin-8-ol, not less than 23 per cent and not more than 40 per cent of 5-chloroquinolin-8-ol and not more than 4 per cent of 7 chloroquinolin-8-ol and the total content of three components is not less than 95 per cent and not more than 105 per cent (Anon., 1980).

Halquinol is a broadspectrum antimicrobial having antibacterial, antifungal, antimycoplasmal and anti-protozoal activity (Stewart, 1958; Heseltine and Campbell, 1960; Lamy, 1964; Fiedler and Kaben, 1966; Ellenrieder and Sensch, 1972; Forster and Duggan, 1974, Cosgrove, 1977; Cosgrove and 
Baines, 1978; Botsoglou and Fletouris, 2001). The absorption of halquinol was negligible following per os administration in rats (Heseltine and Freeman, 1959), thus serve as a potential candidate in the treatment of infections localized within the intestinal tract.

Halquinol is one of the popular molecules marketed in South American and Asian countries including India, for use in poultry as a growth promoter. Antimicrobials specifically antibiotics, incorporated at subtherapeutic doses in animal feeds as growth promoter increases resistance among susceptible microorganisms.

Thus, MIC of antimicrobials changes with time and also varies with regions depending on the usage pattern. Keeping these points in view, the present study was undertaken to determine the current minimum inhibitory concentration of halquinol against bacterial pathogens of poultry origin so as to find its suitability for treating infections by such pathogens in poultry.

\section{Materials and Methods}

\section{Isolation of bacterial pathogens}

The bacterial isolates used in the present study were local isolates viz: Salmonella gallinarum and Escherichia coli (gratis from Department of Veterinary Public Health and Epidemiology, Veterinary College, Bengaluru). The individual isolates of the two species were obtained (taking faecal pellets as sample) from clinical cases of enteritis in poultry as confirmed by standard cultural, morphological and biochemical tests.

The isolates which were stored in glycerol broth at $-20^{\circ} \mathrm{C}$, and were later revived in nutrient broth by incubating overnight at $37^{\circ} \mathrm{C}$ before they were used for inoculation.

\section{MIC determination}

The minimum inhibitory concentration (MIC) of halquinol was determined by employing broth dilution technique following standard protocol (Mackie, 1989; OIE Manual, 2012).

The test was performed by preparing two-fold dilutions of halquinol in series of tubes containing nutrient broth. The macro-dilution method was followed using $5 \mathrm{~mL}$ tubes. In all, 30 tubes of $5 \mathrm{~mL}$ capacity were arranged in two rows with each row containing 15 tubes and each row meant for one particular bacterial isolate. Then $1948.8 \mu \mathrm{L}$ of nutrient broth was added in the first tube in each row and then $1 \mathrm{~mL}$ in the remaining tubes. Now, $51.2 \mu \mathrm{L}$ of antibacterial solution dissolved in appropriate solvent was added to the first tube in each row and after mixing the content, 1 $\mathrm{mL}$ was serially transferred from these tubes to the second tubes in each of the rows (serial two fold dilution). Then the contents of the second tube of each of the rows were mixed and $1 \mathrm{~mL}$ was transferred to the third tube in each of the rows and same procedure was continued up to the last tube and $1 \mathrm{~mL}$ was discarded from last tube in each of the rows. This provided halquinol concentrations of $256,128,64,32,16,8,4,2,1,0.5,0.25,0.12$, $0.06,0.03$ and $0.01 \mu \mathrm{g} / \mathrm{mL}$ in the first to fifteenth tube respectively.

Each tube was inoculated with actively growing pure culture suspension of the test bacterium that contained between $10^{4}$ to $10^{5}$ bacteria/mL. The required concentration of bacteria was achieved by adjusting the bacterial cell suspension turbidity matching to 0.5 on McFarland scale. Two individual isolates from poultry viz., Salmonella gallinarum and Escherichia coli were used in the study as test bacteria.

Drug control and broth controls were maintained following the same procedure but 
without adding bacterial suspension. Culture control was also maintained but without adding the antibacterial. The inoculated tubes of broth were incubated at $35-37^{\circ} \mathrm{C}$ for 24 hrs and then observed for visible growth in the form of turbidity in the tubes. The MIC was determined as the lowest concentration of halquinol that completely inhibited the growth of bacteria (showing no visible growth/no turbidity in the tube).

\section{Results and Discussion}

The current MIC of halquinol as determined by broth dilution following macro dilution technique is $4 \mu \mathrm{g} / \mathrm{mL}$ against both
Escherichia coli and Salmonella gallinarum. The current MIC values of halquinol against both Escherichia coli and Salmonella gallinarum determined in the present study being $4 \mu \mathrm{g} / \mathrm{mL}$, were found to be within the reported global MIC values of halquinol against the same pathogens of poultry viz: Escherichia coli K99, Salmonella gallinarum and Salmonella enteritidis with MIC range of 2 to $7.1 \mu \mathrm{g} / \mathrm{mL}$ (Machado et al., 2015). And also, a study by Cosgrove et al., (1981) has established that addition of halquinol at 120 ppm in a standard grower diet, when fed to pigs over a period of six weeks, did not induce the development of resistance to Escherichia coli.

Fig.1 MIC of halquinol as determined by broth dilution technique

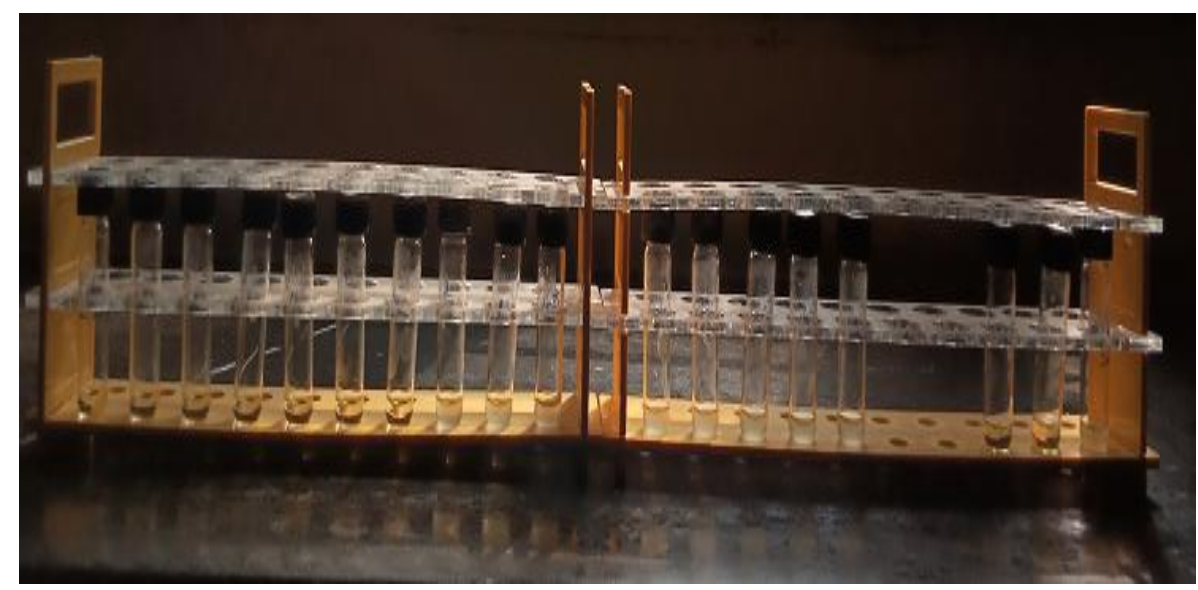

About 40 per cent of antibiotics are used as growth promoters although antibiotics are also used therapeutically for animals. To reduce the risk of selecting resistant bacteria, the use of antibiotics must be restricted. The most attractive area for reducing the use of antibiotics is to ban their use as growth promoters in food animals (Hughes and Heritage, 2004). In such a global scenario of rampant antimicrobial resistance and steps to combat it effectively, halquinol without much evidence of increased resistance over a period of time as reflected by current MIC of 4 $\mu \mathrm{g} / \mathrm{mL}$ against both Escherichia coli and Salmonella gallinarum, can be the viable growth promoter agent compared to other antibiotics in poultry and swine industry.

\section{Acknowledgements}

Acknowledgements are due to Dean (Veterinary) and Director of Research Karnataka Veterinary Animal Fisheries Sciences University, Bidar for providing facilities to conduct the present study.

\section{References}

Anonymous, 1980. British Pharmacopoeia. Her Majesty's Stationery Office: London. 
218-219.

Botsoglou, N. A. and Fletouris, D. J. 2001. Drug residues in foods, In: Antimicrobial growth promoters. Marcel Dekker, New York. pp 189-190.

Cosgrove, R. F. 1977. Rapid microbiological assay for chlorhydroxyquinoline that uses a cryogenically stored inoculum. Antimicrob. Agents Chemother., 11: 848851.

Cosgrove, R. F. and Baines, S. 1978. In vitro activity of chlorohydroxyquinoline against mycoplasma species. Antimicrob. Agents Chemother., 13: 540-541.

Cosgrove, R.F., Forster, T.C., Jones, G.T. and Pickles, R.W. 1981. A study of fluctuations in Escherichia coli sensitivity patterns from pigs fed a halquinol supplemented diet. J. Vet. Pharmacol. Ther., 4: 39-42.

Ellenrieder, V. M. and Sensch, K. H. 1972. The influence of chlorinated oxyquinoline derivatives on anaerobic microorganisms. Arzneim. Forsch., 22: 908909.

Fiedler, H. and Kaben, U. 1966. Antimycotic and antibacterial action of 8 quinolinols and nicotinic acid esters. Pharmazie, 21: 233-238.

Forster, T. C. and Duggan, G. 1974. Proceedings of the $3^{\text {rd }}$ international congress of the international pig veterinary society. Lyon, France, pp 2831.

Heseltine, W. W. and Freeman, F. M. 1959. Some pharmacological and microbiological properties of chlorhydroxyquinoline and related compounds. J. Pharma. Pharmacol., 11: 169-174.
Heseltine, W. W. and Campbell, P. J. 1960. Laboratory studies on chlorhydroxyquinoline, J. Trop. Med. Hyg., 63: 163.

Hughes, P and Heritage, J. 2004. Antibiotic growth promoters in food animals. In: Assessing quality and safety of food animals. (Eds.) Samuel Jutzi. Food and Agriculture Organization of the United Nations publications. Rome. Pp-129.

Lamy, L. 1964. A comparative experimental study of the activity of certain hydroxyquinoline derivatives on multiplication of Entamoeba histolytica cultures and associated bacteria. Ann. Inst. Pasteur Paris, 107: 98-108.

Mackie Mc. Cartney, 1989. Practical Medicinal Microbiology. $13^{\text {th }}$ Edn., Churchill Livingstone, Edinburgh, pp. 87-89.

Machado, A., Milare, M., Carneiro, D. and Zoca, S., 2015. Determination of minimum inhibitory concentration (MIC) for halquinol and its isomer 5, 7dichloro-8-hydroxyquinoline and 5chloro-8-hydroxyquinoline in relation to isolates for Esherichia coli, Salmonella gallinarum and Salmonella enteritidis. International poultry scientific forum Southern conference on avian diseases, Pp-67

OIE Terrestrial Manual, 2012. Part 3, General Guidelines, Guideline 3.1. Laboratory methodologies for bacterial antimicrobial susceptibility testing (Version adopted by the World Assembly of Delegates of the OIE in May 2012), pp 1314-1315.

Stewart, G. T. 1958. Fungus diseases and their treatment. Reddell., R. W. and Stemart, G. T., London, Butterworth.

\section{How to cite this article:}

Pavithra, B. H., N. Prakash, G. Leena and Santhosh, C. R. 2020. Current Minimum Inhibitory Concentration (MIC) of Halquinol against Local Pathogenic Bacterial Isolates of Poultry. Int.J.Curr.Microbiol.App.Sci. 9(08): 799-802. doi: https://doi.org/10.20546/ijcmas.2020.908.085 